\title{
4
}

\section{The root causes of movement: Exploring the determinants of irregular migration from Afghanistan}

\section{Craig Loschmann, Katie Kuschminder and Melissa Siegel}

\section{Introduction}

The occurrence of migration outside of an official system is prevalent throughout the world. Although the precise number of irregular migrants is not known, the International Organization for Migration (IOM) estimated that 10 to 15 per cent of the world's 214 million international migrants in 2010 could be categorised as irregular (IOM, 2010, p. 29). The United Nations Development Programme (UNDP) puts that figure closer to a third, within developing countries alone (UNDP, 2009, p. 23). As a matter of concern for the individual, those embarking on such a journey expose themselves to great risk outside the authority of any formal institution. From the states' perspective, the extent of irregular migration and its political sensitivity can pose great dilemmas for policymakers trying to respond to such flows. Considering the scope and relevance of the issue, the lack of analysis on irregular migration is surprising. 
This chapter explores irregular migration from the (post-)conflict environment of Afghanistan. Our analytical methods are two-fold: first, we sketch a descriptive profile of irregular migrants in order to gain insight into the features of the particular context in question; and second, we empirically model the determinants of irregular migration through standard regression analysis. Regarding the latter, irregular migration is often considered to be simply driven by a lack of ability to migrate through regular channels. While there may be some truth to such a notion, certain characteristics of migrants may also influence decision-making processes. We therefore investigate the role premigration circumstances play, but also look at other relevant migration-related factors, including the period in which migration occurred, destination and principal reasons for migrating, among others.

For both the descriptive and empirical analyses, we rely on a dataset originating from a household survey conducted in Afghanistan in April and May 2011. The survey captured information on 2,005 households across 100 communities. For our purposes, some 16 per cent of all adults observed in the sample are identified as 'irregular', meaning they are either current irregular migrants or former irregular migrants who have since returned.

The remainder of this chapter is structured as follows. We next provide a brief conceptual overview of irregular migration, including definitions and a discussion on determinants. We then outline recent migration trends in Afghanistan in order to better understand the context within which our study is embedded. Following that, we describe our sample and present a descriptive profile of irregular migrants, before moving on to the empirical analysis of the determinants of irregular migration from Afghanistan. Finally, we conclude with a brief discussion of the study's main findings.

\section{Irregular migration: Definitions and caveats}

Critical to defining 'irregular migration' is the recognition of multiple routes into irregularity (Uehling, 2004). The three main routes include individuals entering a country without proper authority, either through clandestine entry or with fraudulent documents; individuals entering with authority, but overstaying their authority; and individuals deliberately utilising the asylum system. The primary distinction of significance for most receiving states is that between irregular entry and irregular stay 
(de Haas, 2008). This chapter focuses on irregular entry, and so an 'irregular migrant' is defined as someone 'crossing borders without proper authority, or violating conditions for entering another country' (Jordan \& Düvell, 2002, p. 15).

In the case at hand, our perspective is that of the country of origin, meaning we look at individuals leaving Afghanistan without proper documentation. Therefore, in practice, we define an irregular migrant within our dataset as an individual who has migrated abroad without official documentation (e.g. tourist visa, work visa, student visa, United Nations High Commissioner for Refugees [UNHCR] refugee status). As such, we do not capture other forms of irregularity like overstaying a visa or abuse of the asylum system, or irregular migrants who become regular through a regularisation scheme. Furthermore, we are unable to identify irregular movement involving smugglers or traffickers.

Beyond terminology, when reflecting on what may influence an individual to migrate irregularly, one must recognise that in most cases migration in general is not driven by a single motivating factor but rather an array of factors which traverse social, economic, environmental and political considerations (de Haas, 2011; Koser \& McAulliffe, 2013). For instance, an individual may seek asylum abroad from political persecution, even though the underlying trigger to migrate may relate to another factor, such as a lack of work opportunities, resulting in a mixed migration motivation. Regardless of the myriad motivations that may drive migration, it seems likely that economic interests are a fundamental factor in decision-making processes (Battistella, 2008).

Moreover, when looking specifically at irregular migration, one must appreciate the parallels with regular migration in that we can expect both to be very much related to the interconnected social, political and economic forces operating in both host and sending countries (van Hear, Bakewell, \& Long, 2012). For example, when the demand for foreign labour is not met by the supply of labour migration through formal channels, people routinely find their own informal, and often creative, ways to meet that demand. Indeed, Portes (1978) found that one of the key defining characteristics of irregular immigration to the US was that such migrants were individuals who move with the sole purpose of selling their work capacity' (p. 472). This consequently leads to the conclusion that the pull of a favourable labour market causes both regular and irregular migration, making distinct identification of the determinants of irregular migration in exclusion a challenge. 
Still, even though it may not be difficult to imagine many of the same factors influencing both irregular and regular migration, there is also indication that the drivers of irregular migration in particular may be specific to the context. Orennius (2001), for example, found that there were five primary factors driving irregular migration from Mexico to the US, a context noticeably different to that of Afghanistan yet still informative: first, the history of migration between the two countries; second, the importance of established networks; third, the availability of smugglers to assist crossing the border; fourth, the large wage gap between the two countries; and fifth, the immigration policies of both countries. Although there are several similarities between the determinants of regular and irregular flows, irregular migration episodes may have certain defining characteristics, and individuals choosing to migrate through irregular channels may embody particular features which influence their decisionmaking process.

\section{Migration trends in Afghanistan}

Often, migration in the Afghan context is viewed solely in relation to the most recent period of conflict, overlooking the fact that cross-border movement in the region has a deep-rooted historical precedence. Prior to the Soviet invasion of 1979, Afghans enjoyed an almost unrestricted ability to move back and forth between both Pakistan and Iran, much of the time for temporary or seasonal employment opportunities (Stitger, 2006). The pull from stronger neighbouring labour markets along with close social and cultural ties helped establish robust social networks across locations (Monsutti, 2006). These networks were utilised and strengthened in the subsequent years of conflict, when many were forced to flee Afghanistan because of extreme insecurity and general hardship.

The conflict in Afghanistan over the last four decades has resulted in one of the worst episodes of protracted forced displacement, both externally and internally, in recent memory. During the Soviet presence over much of the 1980s an estimated 5.8 million people fled to Pakistan and Iran, while another 2 million are believed to have been internally displaced (Strand et al., 2008; Kuschminder \& Dora, 2009). Even though the Soviet withdrawal by the end of the decade offered a brief period of respite, in terms of those seeking refuge abroad, the optimism for calm quickly subsided with heavy infighting between rival mujahedeen factions and the 
Soviet-backed Najibullah regime. In the years up until the government's eventual fall in 1992, the official number of refugees peaked at just over 6.3 million (UNHCR, 2013a).

When the government finally did succumb, Afghanistan experienced a massive return, with more than half of those abroad at the time repatriating within two years. As the Taliban came to power in 1996, however, this considerable inflow came to a halt, only to be reignited following the removal of their regime by international forces in 2001 . The promise of change that came along with the international community's presence in the country post-2001 led to large-scale repatriation, with around 2 million Afghans estimated to have returned in 2002 alone and another 3.7 million since then (UNHCR, 2015). Nonetheless, the Afghan refugee population still remains among the largest in the world, with nearly 2.5 million located in Pakistan and Iran (ibid.). Moreover, the heightened insecurity in recent years has led to a noticeable reduction in the number of people voluntarily repatriating.

Besides official refugees, the number of undocumented Afghans within the immediate region is sizeable. Movement to and from both Pakistan and Iran is fairly fluid, with many lured by job opportunities (Koser, 2014). In Iran alone, an estimated 1.4 million Afghans live without documentation, while another one million are believed to reside in Pakistan (UNHCR, 2013b). Migration outside the region, on the other hand, is relatively small, yet still significant, and in large part is made up of the better educated and highly skilled with the resources and wherewithal to embark on such a journey (Koser, 2014). Nevertheless, the total number of asylum claims by Afghans in mostly industrialised nations has risen in recent years, in response to intensifying violence and possibly in anticipation of the political and security transition that took place in 2014. Estimates show around 85,000 individuals applied for asylum in that year, up from around 75,000 in 2013 and 62,000 in 2012 (UNHCR, 2015).

Overall, migration trends in Afghanistan need to be considered in relation to the context of the moment. Over the last 35 years, mobility has been a fundamental survival strategy for many Afghan families (Monsutti, 2006). Migratory flows have fluctuated greatly, depending on the level of insecurity and the livelihood opportunities available. In light of the most recent transition, whether this modest slowdown in return and rise in requests for asylum turns into a greater trend, and whether such 
movement takes place outside of regular channels, depends on any number of structural factors both within and outside of Afghanistan, as well as the characteristics of the potential migrant.

\section{The survey sample}

This analysis draws on data from a household survey collected for the IS Academy: Migration and Development 'A World in Motion' project. ${ }^{1}$ The objective of the questionnaire was to explore a diverse set of themes related to the relationship between migration and development processes. A range of separate modules provide in-depth information on both individuals and households including general socioeconomic characteristics, migration histories, future migration plans, return migration, remittances, transnational ties and more.

The data collection took place in April and May 2011. While a purely random sample was not possible due to the limitations of conducting fieldwork in high-risk areas of Afghanistan, particular attention was paid to capturing the diversity of the Afghan population in order to increase the representativeness of the sample. In this regard, the five provinces of Kabul, Herat, Balkh, Nangarhar and Kandahar were chosen because of their highly populated urban centres, and the fact that they represent around one third of the entire population. Moreover, they are geographically spread across the five main regions of the country, which allows for a greater representativeness of differing sociodemographic profiles and contextual factors that may influence migration behaviour. Within each province, stratification between urban, semi-rural and rural districts was applied as a way to capture different socioeconomic groups. ${ }^{2}$ Specific communities within these districts were then identified as the primary sampling unit to be eligible for enumeration at random, following official administrative records provided by the Central Statistics

1 Unless otherwose noted, this dataset is the source for all figures and tables in this chapter. For more information about the dataset, see the project homepage: migration.unu.edu/research/ migration-and-development/is-academy-on-migration-and-development-migration-a-world-inmotion.html\#outline.

2 Urban refers to those communities which are the district capital; semi-rural refers to those communities which share a common border with the district capital; and rural refers to those communities with no common border with the district capital. 
Organization of Afghanistan. Additionally, the surveying of households followed a random starting point and fixed interval sampling methodology to increase representativeness within the primary sampling unit.

The sample captures information on individuals within 2,005 households from 100 communities. Table 4.1 provides an overview by regularity status. The vast majority of those individuals with a migration experience migrated without official documentation and therefore irregularly. This is consistent with what we already know of migration in Afghanistan, where movement to and from neighbouring countries outside of any regulated system is common. Whether such individuals were current migrants, meaning they resided abroad for three months or more at the time of the survey, or were once migrants but had since returned is inconsequential to our analysis given the information provided from our questionnaire allows us to group them together based on relevant characteristics. Still, the imbalance between regular and irregular migrants makes comparison between these two groups problematic. Accordingly, the following descriptive profile focuses exclusively on irregular migrants.

Table 4.1: Overview by regularity status

\begin{tabular}{|l|r|r|}
\hline Regularity status & Frequency & Per cent \\
\hline Nonmigrant & 6,195 & 82.57 \\
\hline Regular migrant $^{\star}$ & 86 & 1.15 \\
\hline Irregular migrant $^{\star}$ & 1,222 & 16.29 \\
\hline Total & 7,503 & 100.00 \\
\hline
\end{tabular}

Note: *Current and return migrants, aggregated. Per cent figures rounded to two decimals.

\section{Descriptive profile}

This section highlights premigration features of irregular migrants, including socioeconomic status prior to movement as well as migration-related factors pertaining to the irregular migration episode. We additionally look at the potential for irregular migration in the future, based on migration intentions. Before that, however, we provide an overview of migration and return flows of our sample based on time of departure and return. 
Figure 4.1 depicts a narrative consistent with what we know about the ebb and flow of migration both from and back to Afghanistan. Migration in the pre-1992 period was prevalent due to conflict with the Soviet Union, slightly less so between 1992 and 1996 following the removal of the Najibullah regime, and higher once again in the Taliban years leading up to 2001. The expulsion of the Taliban, however, led to a dip in departures as the number of those leaving in the sample reached its lowest point between 2002 and 2006, yet this decline reversed in the final 5-year time period ending in 2011. Return migration, on the other hand, neatly mirrors these outflows. Return flows in our sample were trivial in the pre1992 period, and increased between 1992 and 1996 before cooling off in the Taliban years up until 2001. The initial post-2001 period, however, witnessed substantial return, with the number repatriating reaching its peak, only to subside again in the final period between 2007 and 2011.

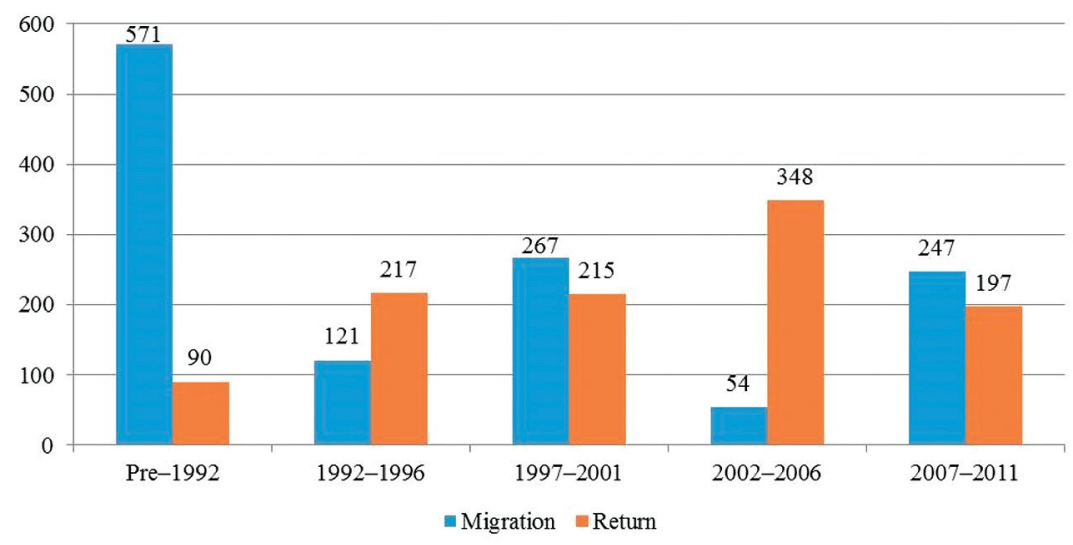

Figure 4.1: Migration and return flows

In terms of the premigration characteristics of irregular migrants, we find that 65 per cent of those with an irregular migration experience were heads of households, more than 80 per cent were male and the average age at departure was 23 years. Figures 4.2 and 4.3 highlight educational attainment and employment status, respectively, of irregular migrants prior to migrating. Figure 4.2 shows that nearly three quarters of our sample had no formal education prior to moving, whereas 14 per cent report primary, 15 per cent secondary and 1 per cent had tertiary level education. The proportion of irregular migrants in our sample with no formal education nearly matches the official measure of the adult Afghan population without any formal schooling at around 75 per cent (Central Statistics Organization, 2014, p. 68). 
Figure 4.3 indicates that a fifth of respondents were employed prior to migrating, while 27 per cent were unemployed and 11 per cent were subsistence farmers. On the other hand, around 40 per cent of the responses were not applicable to employment status, meaning these respondents were either in education, retired, permanently sick or disabled, in community or military service or doing housework. If we take these two indicators to characterise socioeconomic status prior to migration, the results suggest those moving irregularly are generally in a disadvantaged position in society. Indeed, the vast majority of migration without documentation is undertaken by those in the sample with no formal education, and with little to no work experience.

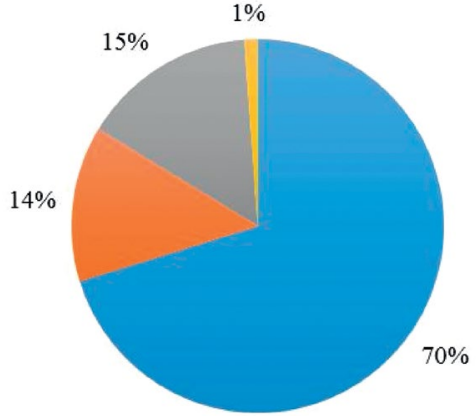

$\llbracket$ No formal $₫$ Primary $₫$ Secondary $₫$ Tertiary

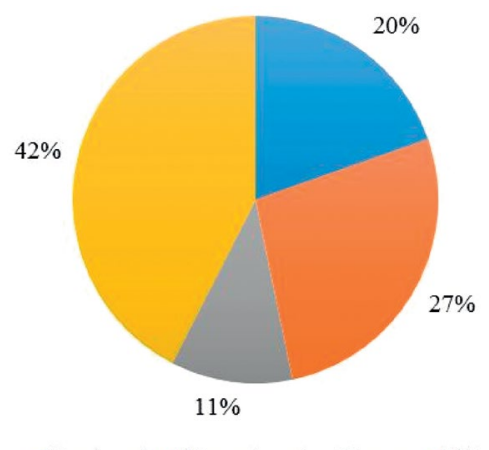

- Employed = Unemployed $=$ Farmer $=$ N/A

Figure 4.2: Educational attainment

Figure 4.3: Employment status

Information on the irregular migration episode helps shed light on migration decision-making processes. Figure 4.4 illustrates the main reasons for migrating by period of migration. Unsurprisingly, we see that prior to the 2001 NATO-led intervention, the vast majority of respondents moved because of security or political considerations.

This is in stark contrast to those leaving just after the international community's arrival and up until 2006, where absolute numbers were far lower and where the predominant reason for moving relates to employment. This trend only intensifies in the last period between 2007 and 2011, with 87 per cent of respondents during this time citing employment as the main reason for migration. Of those responses considered within the 'other' category, reasons for migrating included family reunification or formation (marriage), education, environmental disaster, moving with family and health. 


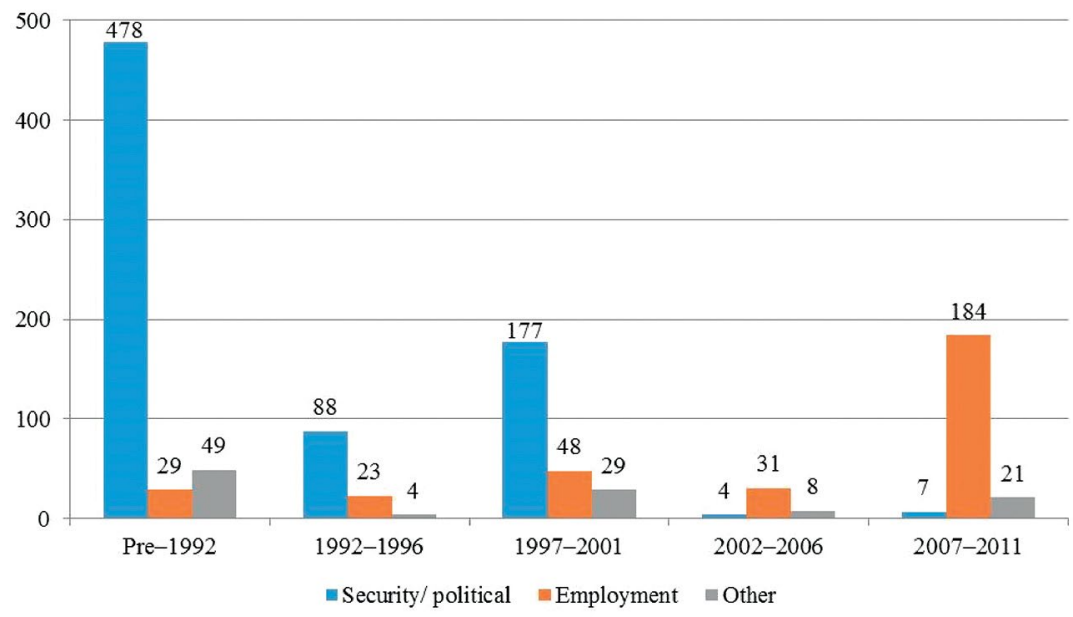

Figure 4.4: Main reason for migration

When it comes to where irregular migrants moved, as expected, nearly all indicated Pakistan or Iran, with 55 per cent going to the former and 43 per cent going to the latter. Of the two per cent who responded 'elsewhere', most specified European countries, including the UK, Belgium and Greece, and there were only a few cases of movement to Saudi Arabia and Tajikistan.

Figure 4.5 provides the main reason for choosing destination by irregular migrants, broken down by each location. Those moving to Pakistan did so mainly because of easy access and entry into the country, though around a quarter cited better working or living conditions. For Iran, however, the main reason is split between easy access or entry and better working or living conditions, suggesting greater job opportunities in comparison to the Pakistani labour market. Lastly, when considering the few moving to locations outside of Iran or Pakistan, better work or living conditions is the predominant reason. Of those who indicated 'other' reasons, responses included 'family or friends already there' and 'to study'.

Besides the individual irregular migrants' motivations for migrating, we are also able to investigate other people involved in both the decision to migrate and act of migration itself. Three quarters of irregular migrants report family members involved in the migration decision, while 19 per cent made the decision alone and 6 per cent counted on friends or others. Furthermore, 63 per cent of respondents migrated with family, while just over a quarter made the journey alone and 11 per cent 
with friends or others. However, when disaggregating by the period of migration, the share of respondents migrating with family is far lower in the post-2001 period compared to the pre-2001 period, 21 per cent compared with 77 per cent respectively, suggesting again that movement since the Taliban's removal is less about entire families fleeing for safety and more about a search for livelihood.

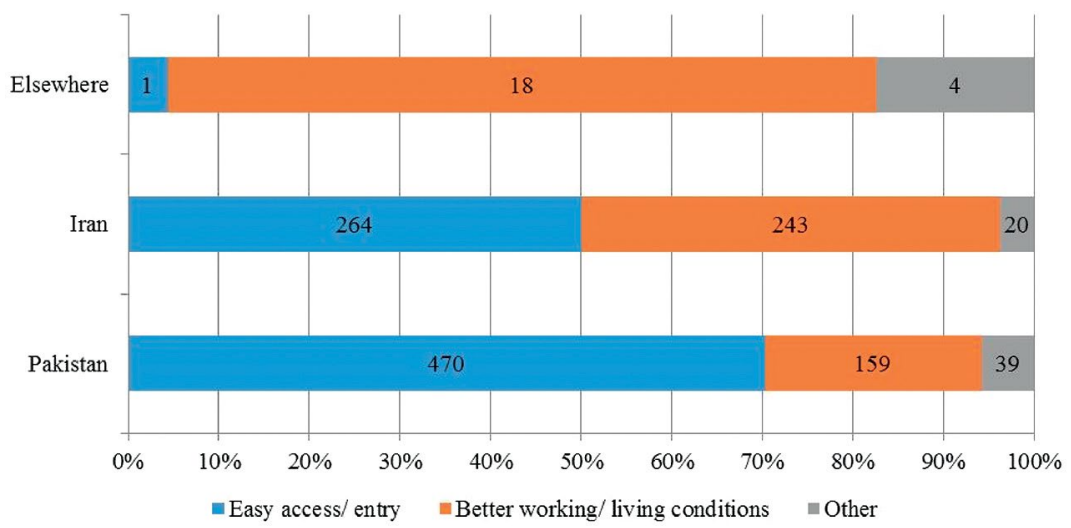

Figure 4.5: Main reason for choosing destination

Turning our attention to social networks, we look at both the contact respondents had with family or friends living abroad prior to migration as well as the financial support they received prior to migration. Only 13 per cent of all irregular migrants had contact with anyone abroad prior to embarking on the journey, suggesting the influence of cross-border networks in this particular case is not as crucial in the decision-making process as is often speculated. A third of respondents relied on either gifts or loans from friends and family to finance their journey in comparison with using savings or selling assets, indicating support at origin was significant for some. However, disaggregating by the period of migration again shows that financial support was much more likely in the post-2001 period in comparison to the pre-2001 period-56 per cent compared with 26 per cent respectively-potentially illustrating that migration motivated by a livelihood strategy is associated with a more robust social network of support.

Finally, we are also able to examine potential future flows of irregular migrants by considering migration aspirations at the time of survey. While 845 individuals in our sample reported having concrete plans to live in another country at some point in the future, only 8 per cent 
of that group were in possession of a valid passport at that time. Of those individuals with migration intentions, 63 per cent intended to move to the 'West', including, in order of priority, the Netherlands, Canada, the UK, Germany, the US and Australia. Conversely, nearly a quarter planned on moving to a 'non-Western' country like Saudi Arabia or the United Arab Emirates, while the remaining 14 per cent cited Iran or Pakistan. When differentiating by whether the respondent had a passport, no clear distinction arises in terms of destination choice. Moreover, when distinguishing by the reason for choosing that particular destination, nearly all respondents indicate better working or living conditions.

\section{Empirical analysis}

This section provides a more detailed empirical analysis using standard regression techniques to identify the determinants of irregular migration from Afghanistan. As mentioned earlier, the extreme imbalance between irregular and regular migrants in our sample complicates our ability to appropriately model determinants for both groups. We therefore provide two separate comparisons: the first, more robust, comparing irregular migrants and nonmigrants; and the second, more tentative comparing irregular migrants and regular migrants. In addition, we also provide the same two comparisons but restrict our sample to those who departed post-2001.

Our empirical approach is to use two separate probit models to estimate the predicted probability of an individual being an irregular migrant in general when comparing to nonmigrants, and in particular when comparing to regular migrants. The formal expression of the probit model is:

$P\left(M_{i}=1 \mid X_{i}\right)=\Phi \beta_{i} X_{i}$

where $M_{i}$ indicates the binary dependent variable of individual $i$ taking the value of 1 if $s /$ he is an irregular migrant, or 0 whether $s /$ he is a nonmigrant and regular migrant respectively. $X_{i}$ is a series of independent variables comprised of basic individual and migration-related characteristics included strictly in the second model. Moreover, $\beta_{i}$ represents the regression parameter to be estimated and $\Phi$ indicates the cumulative normal distribution function. All models are estimated using robust standard errors clustered at the household level, and we report the marginal effects along with their standard errors for easier interpretation. 
Table 4.2 presents the results of the two separate probit models using the whole sample, estimating the predicted probability of an individual being an irregular migrant both generally and in particular. ${ }^{3}$ Beginning with the general model comparing irregular migrants to nonmigrants, a few statistically significant findings stand out. First, a household head and male respondent is on the margin 24 and 2 percentage points more likely to be an irregular migrant, respectively, while older individuals are slightly less likely. Compared to those with no formal education, respondents with some form of educational attainment are less likely to be irregular migrants and the scale of the marginal effect increases with each level. An individual with tertiary education, for example, is 5 percentage points less likely to be an irregular migrant. In terms of employment status, the unemployed are 11 percentage points more likely to be irregular migrants compared to their employed counterparts, whereas the same relationship albeit to a smaller scale exists for subsistence farmers and those with a nonapplicable employment status.

Table 4.2: Probit model

\begin{tabular}{|c|c|c|c|c|}
\hline & \multicolumn{2}{|c|}{ General } & \multicolumn{2}{|c|}{ Particular } \\
\hline Dependent variable & \multicolumn{2}{|c|}{ Irregular migrants } & \multicolumn{2}{|c|}{ Irregular migrants } \\
\hline \multirow[t]{2}{*}{ Base } & \multicolumn{2}{|c|}{ Nonmigrants } & \multicolumn{2}{|c|}{ Regular migrants } \\
\hline & Marginal effect & SE & Marginal effect & SE \\
\hline Household head & $0.2442^{\star \star \star}$ & $(0.0098)$ & 0.0030 & (0.0138) \\
\hline Male & $0.0203^{\star *}$ & $(0.0084)$ & $0.0250^{*}$ & (0.0151) \\
\hline $\mathrm{Age}^{\wedge}$ & $-0.0078^{\star * \star}$ & $(0.0003)$ & -0.0001 & $(0.0004)$ \\
\hline \multicolumn{5}{|l|}{ Educational attainment^^} \\
\hline No formal & Reference & (.) & Reference & (.) \\
\hline Primary & $-0.0247^{\star \star \star}$ & $(0.0084)$ & -0.0115 & (0.0149) \\
\hline Secondary & $-0.0451^{\star \star *}$ & $(0.0066)$ & -0.0047 & $(0.0133)$ \\
\hline Tertiary & $-0.0547^{\star \star \star}$ & $(0.0127)$ & -0.1070 & $(0.1060)$ \\
\hline \multicolumn{5}{|l|}{ Employment status^ } \\
\hline Employed & Reference & (.) & Reference & (.) \\
\hline Unemployed & $0.1121^{\star \star \star}$ & $(0.0191)$ & $0.0281^{*}$ & $(0.0160)$ \\
\hline Subsistence farmer & $0.0520^{\star \star \star}$ & $(0.0155)$ & -0.0176 & $(0.0262)$ \\
\hline Not applicable & $0.0235^{\star \star \star}$ & $(0.0075)$ & 0.0202 & (0.0133) \\
\hline Household size & $0.0029^{\star \star \star}$ & $(0.0011)$ & -0.0006 & (0.0018) \\
\hline
\end{tabular}

3 Summary statistics for all covariates used in the model can be found in Table A1 of the appendix. 
A LONG WAY TO GO

\begin{tabular}{|c|c|c|c|c|}
\hline & \multicolumn{2}{|c|}{ General } & \multicolumn{2}{|c|}{ Particular } \\
\hline Dependent variable & \multicolumn{2}{|c|}{ Irregular migrants } & \multicolumn{2}{|c|}{ Irregular migrants } \\
\hline \multirow[t]{2}{*}{ Base } & \multicolumn{2}{|c|}{ Nonmigrants } & \multicolumn{2}{|c|}{ Regular migrants } \\
\hline & Marginal effect & SE & Marginal effect & SE \\
\hline \multicolumn{5}{|l|}{ Ethnicity } \\
\hline Pashtun & Reference & (.) & Reference & (.) \\
\hline Tajik & 0.0105 & $(0.0072)$ & 0.0067 & $(0.0133)$ \\
\hline Hazara & $0.0595^{\star \star \star}$ & $(0.0195)$ & -0.0119 & (0.0288) \\
\hline Other & -0.0109 & $(0.0128)$ & 0.0172 & $(0.0217)$ \\
\hline \multicolumn{5}{|l|}{ District type } \\
\hline Urban & Reference & (.) & Reference & (.) \\
\hline Semi-rural & -0.0037 & $(0.0070)$ & 0.0096 & $(0.0100)$ \\
\hline Rural & 0.0099 & $(0.0075)$ & -0.0108 & $(0.0139)$ \\
\hline \multicolumn{5}{|l|}{ Province } \\
\hline Nangarhar & Reference & (.) & Reference & (.) \\
\hline Kabul & $0.0201^{* \star}$ & $(0.0096)$ & $-0.0494^{\star \star \star}$ & $(0.0187)$ \\
\hline Herat & 0.0086 & $(0.0100)$ & -0.0327 & $(0.0208)$ \\
\hline Balkh & 0.0028 & (0.0118) & -0.0146 & $(0.0126)$ \\
\hline Kandahar & $-0.0358^{\star \star \star}$ & $(0.0072)$ & -0.0168 & $(0.0150)$ \\
\hline Migration post-2001 & & & $-0.0592^{\star \star \star}$ & (0.0166) \\
\hline \multicolumn{5}{|l|}{ Destination } \\
\hline Pakistan & & & Reference & (.) \\
\hline Iran & & & -0.0163 & (0.0158) \\
\hline Other & & & $-0.3619^{\star \star \star}$ & $(0.1240)$ \\
\hline \multicolumn{5}{|l|}{ Migration reason } \\
\hline Security/political & & & Reference & (.) \\
\hline Employment & & & -0.0026 & $(0.0161)$ \\
\hline Other & & & -0.0073 & $(0.0216)$ \\
\hline \multicolumn{5}{|l|}{ Destination reason } \\
\hline Easy access/entry & & & Reference & (.) \\
\hline Better conditions & & & -0.0156 & $(0.0116)$ \\
\hline Other & & & -0.0007 & $(0.0178)$ \\
\hline \multicolumn{5}{|l|}{ Migration decision } \\
\hline Family & & & Reference & (.) \\
\hline Alone & & & 0.0107 & $(0.0114)$ \\
\hline Friends/other & & & -0.0037 & (0.0293) \\
\hline
\end{tabular}




\begin{tabular}{|c|c|c|c|c|}
\hline & \multicolumn{2}{|c|}{ General } & \multicolumn{2}{|c|}{ Particular } \\
\hline Dependent variable & \multicolumn{2}{|c|}{ Irregular migrants } & \multicolumn{2}{|c|}{ Irregular migrants } \\
\hline \multirow[t]{2}{*}{ Base } & \multicolumn{2}{|c|}{ Nonmigrants } & \multicolumn{2}{|c|}{ Regular migrants } \\
\hline & Marginal effect & SE & Marginal effect & SE \\
\hline \multicolumn{5}{|l|}{ Migrated with } \\
\hline Family & & & Reference & (.) \\
\hline Alone & & & $0.0377^{\star *}$ & $(0.0164)$ \\
\hline Friend/other & & & $0.0559^{\star \star \star}$ & $(0.0120)$ \\
\hline Social networks abroad & & & -0.0179 & $(0.0124)$ \\
\hline \multicolumn{5}{|l|}{ Method to finance trip } \\
\hline Savings/sold assets & & & Reference & (.) \\
\hline Gifts/loans & & & $0.0245^{\star \star}$ & $(0.0107)$ \\
\hline Other & & & 0.0147 & $(0.0179)$ \\
\hline R2 adjusted & 0.3625 & & 0.2300 & \\
\hline $\mathrm{N}$ & 7294 & & 1187 & \\
\hline
\end{tabular}

Note: $\wedge$ indicates information for regular and irregular migrants is prior to migration.

${ }^{\star} p<0.10,{ }^{* \star} p<0.05,{ }^{* \star *} p<0.01$

Looking at some of the standard control variables, those respondents originating from a larger household are slightly more probable to be irregular migrants. Hazaras are 6 percentage points more likely to be irregular in comparison to the Pashtun reference group. As for location, there is no statistically significant difference regarding the type of district one originates from, yet an individual from Kabul is 2 percentage points more likely to be an irregular migrant while those from Kandahar are 4 percentage points less likely in comparison to respondents from Nangarhar.

In the next model, comparing irregular migrants to regular migrants, we observe many of those statistically significant variables from the general model lose significance. Of the basic and premigration individual characteristics, only being male and unemployed leads to a respondent being marginally more likely to be an irregular migrant, both by 3 percentage points. Additionally, an individual from Kabul is now less likely to be an irregular migrant in contrast to that which is seen in the general model. Focusing specifically on those migrationrelated characteristics, we find respondents who moved after 2001 were 6 percentage points less likely to be irregular migrants in comparison to those who moved before international intervention. 
There is no statistically significant difference between Iran and Pakistan; however, those migrating further abroad are much less likely, by 36 percentage points, to be irregular compared to the reference group. Moreover, we see no statistical significance when it comes to the reason one decides to migrate or why one chooses a specific destination, nor depending on who was involved in the migration decision. On the other hand, migrating alone as well as with a friend or other acquaintance is positively correlated with being an irregular migrant in comparison to those who made the journey with family, by 4 and 6 percentage points respectively. Likewise, being supported by family or friends through either a gift or loan in order to finance the migratory trip is associated with being slightly more likely to be an irregular migrant, by 2 percentage points, in relation to those who relied on savings or sold assets.

Despite irregular migration post-2001 being less prevalent than in the period prior, as indicated in the previous model there is reason to believe the nature of flows during this interval is fundamentally distinct in comparison to migration pre-2001. With this in mind, Table 4.3 presents the results of the same two models but with a restricted sample for those who departed post-2001. ${ }^{4}$ Beginning once again with the general model, we find similarly that a household head and male respondent is more likely to be an irregular migrant. Still, the marginal scale of the variable indicating head of household is much lower than before, suggesting a slight change regarding which member migrates within the household. Age at departure still shows a negative sign despite being negligible. Concerning educational attainment, here only those respondents with secondary and tertiary qualifications are less likely to be irregular migrants, with the marginal scale again lower than that found earlier. With regard to employment status, now only a subsistence farmer is less likely to be an irregular migrant in comparison to an employed individual, again with marginal effects dampened.

4 Summary statistics for all covariates used in the model can be found in Table A2 of the appendix. 
Table 4.3: Probit model, post-2001

\begin{tabular}{|c|c|c|c|c|}
\hline & \multicolumn{2}{|c|}{ General, post-2001 } & \multicolumn{2}{|c|}{ Particular, post-2001 } \\
\hline Dependent variable & \multicolumn{2}{|c|}{ Irregular migrants } & \multicolumn{2}{|c|}{ Irregular migrants } \\
\hline \multirow[t]{2}{*}{ Base } & \multicolumn{2}{|c|}{ Nonmigrants } & \multicolumn{2}{|c|}{ Regular migrants } \\
\hline & Marginal effect & SE & Marginal effect & SE \\
\hline Household head & $0.0084^{\star \star \star}$ & $(0.0026)$ & -0.0005 & $(0.0440)$ \\
\hline Male & $0.0274^{\star \star \star}$ & $(0.0041)$ & $0.1313^{\star *}$ & $(0.0562)$ \\
\hline $\mathrm{Age}^{\wedge}$ & $-0.0009^{\star \star \star}$ & $(0.0001)$ & -0.0015 & $(0.0015)$ \\
\hline \multicolumn{5}{|l|}{ Educational attainment^ } \\
\hline No formal & Reference & (.) & Reference & (.) \\
\hline Primary & -0.0034 & $(0.0024)$ & -0.0588 & (0.0538) \\
\hline Secondary & $-0.0068^{\star \star \star}$ & $(0.0021)$ & 0.0122 & (0.0289) \\
\hline Tertiary & $-0.0108^{\star \star \star}$ & $(0.0027)$ & -0.0857 & $(0.1966)$ \\
\hline \multicolumn{5}{|l|}{ Employment status^ } \\
\hline Employed & Reference & (.) & Reference & (.) \\
\hline Unemployed & 0.0057 & $(0.0063)$ & $0.0971^{\text {***}}$ & $(0.0364)$ \\
\hline Subsistence farmer & $-0.0104^{\star \star \star}$ & $(0.0029)$ & 0.0520 & $(0.0811)$ \\
\hline Not applicable & -0.0040 & $(0.0028)$ & 0.0583 & $(0.0416)$ \\
\hline Household size & $0.0006^{\star}$ & $(0.0004)$ & -0.0008 & $(0.0056)$ \\
\hline \multicolumn{5}{|l|}{ Ethnicity } \\
\hline Pashtun & Reference & (.) & Reference & (.) \\
\hline Tajik & 0.0024 & $(0.0025)$ & 0.0160 & $(0.0387)$ \\
\hline Hazara & $0.0150^{*}$ & $(0.0084)$ & -0.1458 & $(0.1296)$ \\
\hline Other & $-0.0060^{\star *}$ & $(0.0025)$ & 0.0000 & (.) \\
\hline \multicolumn{5}{|l|}{ District type } \\
\hline Urban & Reference & (.) & Reference & (.) \\
\hline Semi-rural & 0.0001 & $(0.0020)$ & 0.0062 & $(0.0324)$ \\
\hline Rural & $0.0126^{\star \star \star}$ & $(0.0034)$ & -0.0305 & $(0.0457)$ \\
\hline \multicolumn{5}{|l|}{ Province } \\
\hline Nangarhar & Reference & (.) & Reference & (.) \\
\hline Kabul & $0.0048^{*}$ & $(0.0028)$ & -0.0987 & $(0.0627)$ \\
\hline Herat & $0.0293^{\star * \star}$ & $(0.0059)$ & -0.0805 & $(0.0521)$ \\
\hline Balkh & $0.0204^{\star \star \star}$ & $(0.0058)$ & -0.0351 & $(0.0254)$ \\
\hline Kandahar & $-0.0043^{\star \star}$ & $(0.0018)$ & -0.0274 & (0.0602) \\
\hline
\end{tabular}


A LONG WAY TO GO

\begin{tabular}{|c|c|c|c|c|}
\hline & \multicolumn{2}{|c|}{ General, post-2001 } & \multicolumn{2}{|c|}{ Particular, post-2001 } \\
\hline Dependent variable & \multicolumn{2}{|c|}{ Irregular migrants } & \multicolumn{2}{|c|}{ Irregular migrants } \\
\hline \multirow[t]{2}{*}{ Base } & \multicolumn{2}{|c|}{ Nonmigrants } & \multicolumn{2}{|c|}{ Regular migrants } \\
\hline & Marginal effect & SE & Marginal effect & SE \\
\hline \multicolumn{5}{|l|}{ Destination } \\
\hline Pakistan & & & Reference & (.) \\
\hline Iran & & & -0.0232 & $(0.0309)$ \\
\hline Other & & & $-0.6232^{\star \star \star}$ & $(0.1813)$ \\
\hline \multicolumn{5}{|l|}{ Migration reason } \\
\hline Security/political & & & Reference & (.) \\
\hline Employment & & & 0.0209 & $(0.0663)$ \\
\hline Other & & & 0.0767 & $(0.0626)$ \\
\hline \multicolumn{5}{|l|}{ Destination reason } \\
\hline Easy access/entry & & & Reference & (.) \\
\hline Better conditions & & & -0.0101 & $(0.0278)$ \\
\hline Other & & & -0.0829 & $(0.0862)$ \\
\hline \multicolumn{5}{|l|}{ Migration decision } \\
\hline Family & & & Reference & (.) \\
\hline Alone & & & -0.0080 & $(0.0329)$ \\
\hline Friends/other & & & 0.0000 & (.) \\
\hline \multicolumn{5}{|l|}{ Migrated with } \\
\hline Family & & & Reference & (.) \\
\hline Alone & & & 0.1294 & $(0.1014)$ \\
\hline Friend/other & & & $0.2171^{\star *}$ & $(0.0884)$ \\
\hline Social networks abroad & & & -0.0320 & $(0.0355)$ \\
\hline \multicolumn{5}{|l|}{ Method to finance trip } \\
\hline Savings/sold assets & & & Reference & (.) \\
\hline Gifts/loans & & & $0.1045^{\star \star}$ & $(0.0471)$ \\
\hline Other & & & 0.0958 & $(0.0603)$ \\
\hline R2 adjusted & 0.2463 & & 0.3847 & \\
\hline $\mathrm{N}$ & 6421 & & 272 & \\
\hline
\end{tabular}

Note: $\wedge$ indicates information for regular and irregular migrants is prior to migration.

${ }^{\star} \mathrm{p}<0.10,{ }^{* *} \mathrm{p}<0.05,{ }^{* * *} \mathrm{p}<0.01$

Regarding control variables, most results are similar, yet with a lower marginal effect despite a few variables gaining statistical significance. In reference to those variables specifying location, it seems an individual 
from a rural district as well as from Herat and Balkh provinces is now slightly more likely to be an irregular migrant. Considering that migration post-2001 is motivated more by employment opportunities abroad, it is unsurprising that rural households now are more likely to be the origin of irregular migrants than their urban counterparts. Moreover, the statistical significance of provinces like Herat and Balkh post-2001 may indicate a more recent dispersion from where irregular migrants originate.

Finally, looking at the particular model again we see once more that most of those statistically significant variables in the general model lose significance. Still, being male and unemployed remain statistically significant and positive, and actually gain in scale in comparison to the situation when the whole sample is in the analysis. Additionally, considering migration flows are more likely driven by employment since 2001, the 10 per cent marginal effect for the unemployed variable is telling. Beyond this result, however, all other statistically significant results are similar to what was seen before, including destination other than Pakistan or Iran, migrating with a friend or other acquaintance and relying on gifts or loans in order to finance the trip. Nevertheless, the marginal effect for each is amplified compared to the model using the whole sample, with the latter two again potentially indicating a greater social element to the migration event when motivated by the search for livelihood opportunities.

\section{Conclusions}

Despite the widespread occurrence of irregular migration in both the developed and developing world, there is a gap in understanding the specific determinants of irregular migration. This study has aimed to contribute to filling this research gap by exploring the determinants of irregular migration within the (post-) conflict environment of Afghanistan, taking both a descriptive and empirical approach. Relying on a unique dataset, we first profile irregular migrants in our sample and second model the determinants of being an irregular migrant for both the whole sample and those who migrated post-2001.

The descriptive profile paints a consistent picture regarding what we know about the history of migration in Afghanistan. Over the last 35 years, migration has ebbed and flowed in response to both insecurity and the lack of livelihood opportunities. Despite the rise and fall in migration flows, irregular cross-border movement has been common throughout 
this time period, especially to and from neighbouring Pakistan and Iran. The results highlight that the vast majority of migration from Afghanistan has been, and will continue to be, irregular.

The descriptive analysis indicates that those who move irregularly are predominately of a lower socioeconomic status, with little to no schooling and limited work experience. Moreover, the main reason for migrating has shifted over time. Unsurprisingly, migration was primarily motivated by security or political considerations prior to 2001, whereas since then it has been primarily driven by the search for employment. This emphasis on migration for livelihood is greater for those moving to Iran for those moving to Pakistan, which may indicate the greater demand for lowskilled labour in Iran due to the nature of its economy. Likewise, the fact that migrating alone is more prevalent post-2001, and that the trip is also more likely financed through gifts or loans from family and friends, gives credence to the notion of migration for livelihood potentially being based on a strategy at the household level. Finally, taking into consideration the intentions to migrate of those individuals without an official passport suggests irregular migration is likely to continue into the near future.

As for the empirical analysis focusing on the determinants of migration, we notice a number of premigration characteristics of statistical significance. In the general model, individuals with a lower educational background are consistently more likely to be irregular migrants compared to nonmigrants. There is also evidence in both the general and particular models that those with less employment experience are more likely to migrate, yet the statistical significance varies across specification. Regarding location, it seems the origin of irregular migrants has dispersed more recently to include mostly rural areas and more provinces.

When it comes to migration-related factors, we find irregular migration to be less likely in the post-2001 period than in the previous period, even though it still dominates overall flows. Moreover, our analysis finds evidence that those individuals migrating beyond neighbouring Pakistan and Iran, which in this case was primarily to various European countries and Saudi Arabia, are less likely to have made the journey through irregular channels. It is important to note, however, that most research on irregular Afghan migration to other countries, such as Australia and those in Europe, does find that the majority of these flows are irregular (Boland, 2010; Koser \& McAuliffe, 2013; Vervliet, Vanobbergen, Broekaert, $\&$ Derluyn, 2015). Even though the number of individuals in our sample 
that did move outside of Pakistan and Iran is limited, this finding may still indicate the difficulties in doing so given the associated costs and distance. Additionally, those respondents migrating with a friend or other acquaintance are more likely to be irregular migrants in comparison to those individuals migrating with family, while the same goes for those relying on financial support from family or friends to finance the journey. This last finding again potentially indicates the importance of social networks when migration is motivated by the search for employment, possibly as part of an implicit household strategy to diversify the overall sources of livelihood.

\section{Reference list}

Battistella, G. (2008). Irregular migration. In Appave, G., \& Cholewinski, R. (Eds), World migration 2008 (pp. 201-34). Washington DC: Inter-American Development Bank.

Boland, K. (2010). Children on the move between Afghanistan and western countries. Geneva: United Nations Children's Fund.

Central Statistics Organization. (2014). National Risk and Vulnerability Assessment 2011/2012. Afghanistan Living Conditions Survey. Kabul: Author.

de Haas, H. (2008). Irregular migration from West Africa to the Maghreb and the European Union: An overview of recent trends. Geneva: International Organization for Migration.

de Haas, H. (2011). The determinants of international migration: Conceptualizing policy, origin and destination effects. Determinants of International Migration, project paper no. 2. Oxford: International Migration Institute.

International Organization for Migration. (2010). World Migration Report 2010. Geneva: Author.

Jordan, B., \& Düvell, F. (2002). Irregular migration: Dilemmas of transnational mobility. Aldershot: Edward Elgar.

Koser, K. (2014). Transition, crisis and mobility in Afghanistan: Rhetoric and reality. Geneva: International Organization for Migration. 
Koser, K., \& McAuliffe, M. (2013). Establishing an evidence-base for future policy development on irregular migration to Australia. Irregular Migration Research Program, Occasional Paper Series 01. Canberra: Australian Department of Immigration and Citizenship. Retrieved from www.border.gov.au/ReportsandPublications/Documents/research/ evidence-base-for-future-policy.pdf.

Kuschminder, K., \& Dora, M. (2009). Migration in Afghanistan: History, current trends and future prospects. Paper series: Migration and development country profiles. Maastricht: Maastricht Graduate School of Governance.

Monsutti, A. (2006). Afghan transnational networks: Looking beyond repatriation. Kabul: Afghan Research and Evaluation Unit.

Orrenius, P. M. (2001). Illegal immigration and enforcement along the US-Mexico border: An overview. Economic and Financial Review, 1(1), 2-11.

Portes, A. (1978). Introduction: toward a structural analysis of illegal (undocumented) immigration. International Migration Review, 12(4), 469-84. doi.org/10.2307/2545446

Stitger, E. (2006). Afghan migratory strategies-An assessment of repatriation and sustainable return in response to the convention plus. Refugee Survey Quarterly, 25(2): 109-22. doi.org/10.1093/rsq/ hdi0129

Strand, A., Akbari, A., Chaudhary, T. W., Harpviken, K. B., Sarwari, A., \& Suhrke, A. (2008). Return in Dignity, Return to What? Review of the Voluntary Return Programme to Afghanistan. Bergen: Chr. Michelsen Institute.

Uehling, G. (2004). Unwanted migration: combating and unwittingly creating irregular migration in Ukraine. New Issues in Refugee Research, working paper no. 109. Geneva: United Nations High Commissioner for Refugees.

United Nations Development Programme. (2009). Human development report 2009. Overcoming barriers: Human mobility and development. Geneva: Author. doi.org/10.18356/9d335cec-en

United Nations High Commissioner for Refugees. (2013a). Global trends 2012-Displacement: The new 21st century challenge. Geneva: Author. 
United Nations High Commissioner for Refugees. (2013b). Solutions strategy for Afghan refugees: Summary progress report. Geneva: Author.

United Nations High Commissioner for Refugees. (2015). UNHCR statistical online population database. Data extracted July 23, 2015. Retrieved from popstats.unhcr.org.

van Hear, N., Bakewell, O., \& Long, K. (2012). Drivers of migration. Migrating out of poverty, working paper no. 1. Oxford: University of Oxford.

Vervliet, M., Vanobbergen, B., Broekaert, E., \& Derluyn, I. (2015). The aspirations of Afghan unaccompanied refugee minors before departure and on arrival in the host country. Childhood, 22(3), 1-16.

\section{Appendix}

Table A1: Summary statistics

\begin{tabular}{|c|c|c|c|c|c|c|}
\hline \multirow[b]{2}{*}{ Variable } & \multicolumn{2}{|c|}{ Nonmigrant } & \multicolumn{2}{|c|}{ Regular migrant } & \multicolumn{2}{|c|}{ Irregular migrant } \\
\hline & Mean & SD & Mean & SD & Mean & SD \\
\hline Household head & 0.19 & $(0.39)$ & 0.37 & $(0.49)$ & 0.65 & $(0.48)$ \\
\hline Male & 0.48 & $(0.50)$ & 0.72 & $(0.45)$ & 0.82 & $(0.39)$ \\
\hline $\mathrm{Age}^{\wedge}$ & 34.16 & (15.99) & 25.53 & (12.09) & 23.37 & (13.13) \\
\hline \multicolumn{7}{|l|}{ Educational attainment^^ } \\
\hline No formal & 0.67 & $(0.47)$ & 0.59 & $(0.49)$ & 0.70 & $(0.46)$ \\
\hline Primary & 0.11 & $(0.31)$ & 0.16 & $(0.37)$ & 0.13 & $(0.34)$ \\
\hline Secondary & 0.19 & $(0.39)$ & 0.21 & $(0.41)$ & 0.15 & $(0.36)$ \\
\hline Tertiary & 0.03 & $(0.16)$ & 0.03 & $(0.18)$ & 0.01 & $(0.11)$ \\
\hline \multicolumn{7}{|l|}{ Employment status^ } \\
\hline Employed & 0.23 & $(0.42)$ & 0.42 & $(0.50)$ & 0.27 & $(0.45)$ \\
\hline Unemployed & 0.04 & $(0.20)$ & 0.05 & $(0.21)$ & 0.12 & $(0.33)$ \\
\hline Subsistence farmer & 0.04 & $(0.19)$ & 0.09 & $(0.29)$ & 0.11 & $(0.31)$ \\
\hline Not applicable & 0.69 & $(0.46)$ & 0.44 & $(0.50)$ & 0.50 & $(0.50)$ \\
\hline Household size & 8.29 & $(2.81)$ & 8.20 & (2.58) & 7.72 & $(2.75)$ \\
\hline \multicolumn{7}{|l|}{ Ethnicity } \\
\hline Pashtun & 0.47 & $(0.50)$ & 0.37 & $(0.49)$ & 0.45 & $(0.50)$ \\
\hline Tajik & 0.41 & $(0.49)$ & 0.44 & $(0.50)$ & 0.42 & $(0.49)$ \\
\hline
\end{tabular}


A LONG WAY TO GO

\begin{tabular}{|c|c|c|c|c|c|c|}
\hline \multirow[b]{2}{*}{ Variable } & \multicolumn{2}{|c|}{ Nonmigrant } & \multicolumn{2}{|c|}{ Regular migrant } & \multicolumn{2}{|c|}{ Irregular migrant } \\
\hline & Mean & SD & Mean & SD & Mean & SD \\
\hline Hazara & 0.05 & $(0.22)$ & 0.17 & (0.38) & 0.08 & $(0.27)$ \\
\hline Other & 0.06 & $(0.24)$ & 0.01 & $(0.11)$ & 0.05 & $(0.21)$ \\
\hline \multicolumn{7}{|l|}{ District type } \\
\hline Urban & 0.51 & $(0.50)$ & 0.50 & $(0.50)$ & 0.49 & $(0.50)$ \\
\hline Semi-rural & 0.24 & $(0.42)$ & 0.20 & $(0.40)$ & 0.26 & $(0.44)$ \\
\hline Rural & 0.26 & $(0.44)$ & 0.30 & $(0.46)$ & 0.25 & $(0.44)$ \\
\hline \multicolumn{7}{|l|}{ Province } \\
\hline Nangarhar & 0.22 & $(0.42)$ & 0.14 & $(0.35)$ & 0.24 & $(0.42)$ \\
\hline Kabul & 0.21 & $(0.40)$ & 0.31 & $(0.47)$ & 0.22 & $(0.41)$ \\
\hline Herat & 0.17 & $(0.37)$ & 0.19 & $(0.39)$ & 0.20 & $(0.40)$ \\
\hline Balkh & 0.20 & $(0.40)$ & 0.29 & $(0.46)$ & 0.19 & (0.39) \\
\hline Kandahar & 0.21 & $(0.40)$ & 0.07 & $(0.26)$ & 0.15 & $(0.36)$ \\
\hline Migration post-2001 & & & 0.57 & $(0.50)$ & 0.22 & $(0.41)$ \\
\hline \multicolumn{7}{|l|}{ Destination } \\
\hline Pakistan & & & 0.25 & $(0.44)$ & 0.55 & $(0.50)$ \\
\hline Iran & & & 0.60 & $(0.49)$ & 0.43 & $(0.50)$ \\
\hline Other & & & 0.15 & $(0.36)$ & 0.02 & $(0.14)$ \\
\hline \multicolumn{7}{|l|}{ Migration reason } \\
\hline Security/political & & & 0.40 & $(0.49)$ & 0.63 & $(0.48)$ \\
\hline Employment & & & 0.47 & $(0.50)$ & 0.28 & $(0.45)$ \\
\hline Other & & & 0.14 & $(0.35)$ & 0.10 & $(0.29)$ \\
\hline \multicolumn{7}{|l|}{ Destination reason } \\
\hline Easy access/entry & & & 0.33 & $(0.47)$ & 0.60 & $(0.49)$ \\
\hline Better conditions & & & 0.58 & $(0.50)$ & 0.35 & $(0.48)$ \\
\hline Other & & & 0.09 & $(0.29)$ & 0.05 & $(0.22)$ \\
\hline \multicolumn{7}{|l|}{ Migration decision } \\
\hline Family & & & 0.77 & $(0.42)$ & 0.75 & $(0.43)$ \\
\hline Alone & & & 0.20 & $(0.40)$ & 0.19 & $(0.39)$ \\
\hline Friends/other & & & 0.02 & $(0.15)$ & 0.07 & $(0.25)$ \\
\hline \multicolumn{7}{|l|}{ Migration with } \\
\hline Family & & & 0.62 & $(0.49)$ & 0.63 & $(0.48)$ \\
\hline Alone & & & 0.35 & $(0.48)$ & 0.25 & $(0.43)$ \\
\hline Friend/other & & & 0.03 & $(0.18)$ & 0.12 & $(0.32)$ \\
\hline Social networks abroad & & & 0.19 & (0.39) & 0.13 & $(0.34)$ \\
\hline
\end{tabular}




\begin{tabular}{|l|c|c|c|c|c|c|}
\hline & \multicolumn{2}{|c|}{ Nonmigrant } & \multicolumn{2}{c|}{ Regular migrant } & \multicolumn{2}{c|}{ Irregular migrant } \\
\hline Variable & Mean & SD & Mean & SD & Mean & SD \\
\hline Method to finance trip & & & 0.58 & $(0.50)$ & 0.60 & $(0.49)$ \\
\hline Savings/sold assets & & & 0.31 & $(0.47)$ & 0.33 & $(0.47)$ \\
\hline Gifts/loans & & & 0.10 & $(0.31)$ & 0.07 & $(0.25)$ \\
\hline Other & & &
\end{tabular}

Note: $\wedge$ indicates information for regular and irregular migrants is prior to migration.

Table A2: Summary statistics, post-2001

\begin{tabular}{|c|c|c|c|c|c|c|}
\hline \multirow[b]{2}{*}{ Variable } & \multicolumn{2}{|c|}{ Nonmigrant } & \multicolumn{2}{|c|}{ Regular migrant } & \multicolumn{2}{|c|}{ Irregular migrant } \\
\hline & Mean & SD & Mean & SD & Mean & SD \\
\hline Household head & 0.19 & $(0.39)$ & 0.22 & $(0.42)$ & 0.30 & $(0.46)$ \\
\hline Male & 0.48 & $(0.50)$ & 0.70 & $(0.47)$ & 0.93 & $(0.26)$ \\
\hline Age $^{\wedge}$ & 34.17 & $(15.99)$ & 27.42 & $(10.72)$ & 24.85 & (9.61) \\
\hline \multicolumn{7}{|l|}{ Educational attainment^ } \\
\hline No formal & 0.67 & $(0.47)$ & 0.52 & (0.51) & 0.58 & $(0.50)$ \\
\hline Primary & 0.11 & $(0.31)$ & 0.24 & $(0.43)$ & 0.18 & $(0.39)$ \\
\hline Secondary & 0.19 & $(0.39)$ & 0.22 & $(0.42)$ & 0.23 & $(0.42)$ \\
\hline Tertiary & 0.03 & $(0.16)$ & 0.02 & $(0.15)$ & 0.01 & $(0.09)$ \\
\hline \multicolumn{7}{|l|}{ Employment status^ } \\
\hline Employed & 0.23 & $(0.42)$ & 0.47 & $(0.50)$ & 0.42 & $(0.49)$ \\
\hline Unemployed & 0.04 & $(0.19)$ & 0.02 & $(0.15)$ & 0.04 & $(0.19)$ \\
\hline Subsistence farmer & 0.04 & $(0.20)$ & 0.04 & $(0.21)$ & 0.09 & $(0.29)$ \\
\hline Not applicable & 0.69 & $(0.46)$ & 0.47 & $(0.50)$ & 0.45 & $(0.50)$ \\
\hline Household size & 8.29 & $(2.81)$ & 8.17 & $(2.54)$ & 8.02 & (2.73) \\
\hline \multicolumn{7}{|l|}{ Ethnicity } \\
\hline Pashtun & 0.47 & $(0.50)$ & 0.28 & $(0.46)$ & 0.26 & $(0.44)$ \\
\hline Tajik & 0.41 & $(0.49)$ & 0.50 & $(0.51)$ & 0.59 & $(0.49)$ \\
\hline Hazara & 0.05 & $(0.22)$ & 0.22 & $(0.42)$ & 0.10 & $(0.30)$ \\
\hline Other & 0.06 & $(0.24)$ & 0.00 & $(0.00)$ & 0.04 & $(0.20)$ \\
\hline \multicolumn{7}{|l|}{ District type } \\
\hline Urban & 0.51 & $(0.50)$ & 0.54 & $(0.50)$ & 0.40 & $(0.49)$ \\
\hline Semi-rural & 0.24 & $(0.42)$ & 0.20 & $(0.40)$ & 0.20 & $(0.40)$ \\
\hline Rural & 0.26 & $(0.44)$ & 0.26 & $(0.44)$ & 0.41 & $(0.49)$ \\
\hline \multicolumn{7}{|l|}{ Province } \\
\hline Nangarhar & 0.22 & $(0.42)$ & 0.17 & (0.38) & 0.11 & (0.32) \\
\hline
\end{tabular}


A LONG WAY TO GO

\begin{tabular}{|c|c|c|c|c|c|c|}
\hline \multirow[b]{2}{*}{ Variable } & \multicolumn{2}{|c|}{ Nonmigrant } & \multicolumn{2}{|c|}{ Regular migrant } & \multicolumn{2}{|c|}{ Irregular migrant } \\
\hline & Mean & SD & Mean & SD & Mean & SD \\
\hline Kabul & 0.21 & $(0.40)$ & 0.15 & $(0.36)$ & 0.18 & $(0.38)$ \\
\hline Herat & 0.17 & $(0.37)$ & 0.24 & $(0.43)$ & 0.34 & $(0.47)$ \\
\hline Balkh & 0.20 & $(0.40)$ & 0.41 & $(0.50)$ & 0.33 & $(0.47)$ \\
\hline Kandahar & 0.21 & $(0.40)$ & 0.02 & $(0.15)$ & 0.04 & $(0.20)$ \\
\hline \multicolumn{7}{|l|}{ Destination } \\
\hline Pakistan & & & 1.00 & $(0.00)$ & 1.00 & $(0.00)$ \\
\hline Iran & & & 0.07 & $(0.25)$ & 0.13 & $(0.34)$ \\
\hline Other & & & 0.66 & $(0.48)$ & 0.81 & (0.39) \\
\hline \multicolumn{7}{|l|}{ Migration reason } \\
\hline Security/political & & & 0.27 & $(0.45)$ & 0.05 & $(0.23)$ \\
\hline Employment & & & 0.13 & (0.34) & 0.04 & $(0.20)$ \\
\hline Other & & & 0.72 & $(0.46)$ & 0.84 & $(0.36)$ \\
\hline \multicolumn{7}{|l|}{ Destination reason } \\
\hline Easy access/entry & & & 0.15 & $(0.36)$ & 0.11 & $(0.32)$ \\
\hline Better conditions & & & 0.24 & $(0.43)$ & 0.41 & $(0.49)$ \\
\hline Other & & & 0.59 & $(0.50)$ & 0.55 & $(0.50)$ \\
\hline \multicolumn{7}{|l|}{ Migration decision } \\
\hline Family & & & 0.17 & $(0.38)$ & 0.04 & $(0.20)$ \\
\hline Alone & & & 0.69 & $(0.47)$ & 0.63 & $(0.48)$ \\
\hline Friends/other & & & 0.00 & $(0.00)$ & 0.04 & $(0.19)$ \\
\hline \multicolumn{7}{|l|}{ Migration with } \\
\hline Family & & & 0.31 & $(0.47)$ & 0.33 & $(0.47)$ \\
\hline Alone & & & 0.48 & $(0.51)$ & 0.16 & $(0.37)$ \\
\hline Friend/other & & & 0.04 & $(0.21)$ & 0.29 & $(0.45)$ \\
\hline Social networks abroad & & & 0.22 & $(0.42)$ & 0.14 & $(0.35)$ \\
\hline Method to finance trip & & & 0.48 & $(0.51)$ & 0.55 & $(0.50)$ \\
\hline Savings/sold assets & & & 0.57 & $(0.50)$ & 0.25 & $(0.44)$ \\
\hline Gifts/loans & & & 0.35 & $(0.48)$ & 0.60 & $(0.49)$ \\
\hline Other & & & 0.09 & $(0.28)$ & 0.15 & (0.36) \\
\hline
\end{tabular}

Note: $\wedge$ indicates information for regular and irregular migrants is prior to migration. 
This text is taken from A Long Way to Go: Irregular Migration Patterns, Processes, Drivers and Decision-making, edited by Marie McAuliffe and Khalid Koser, published 2017 by ANU Press, The Australian National University, Canberra, Australia.

dx.doi.org/10.22459/LWG.12.2017.04 